\title{
PENDEKATAN NEUTROSOPHIC SET UNTUK SEGMENTASI CITRA ULTRASONOGRAFI PAYUDARA BERDASARKAN METODE OTSU
}

\author{
M. Rahmawaty ${ }^{1}$, Y. Triyani $^{2}$ \\ ${ }^{1}$ Jurusan Teknologi Industri/Program Studi Teknik Mekatronika, Politeknik Caltex Riau \\ Pekanbaru, Indonesia \\ 2Jurusan Teknologi Industri/Program Studi Teknik Telekomunikasi, Politeknik Caltex Riau \\ Pekanbaru, Indonesia \\ e-mail:made@pcr.ac.id, yuli@pcr.ac.id
}

\begin{abstract}
Abstrak
Kanker payudara merupakan penyebab utama kematian perempuan di seluruh dunia. Deteksi batas nodul yang yang tepat, penting dalam mendiagnosis kanker payudara. Metode segmentasi yang akurat sangat penting dalam keberhasilan diagnosis. Ultrasonografi (USG) merupakan alat screening yang efektif untuk deteksi keganasan. Namun adanya speckle noise dan kontras yang rendah pada citra ultrasonografi payudara dapat mempengaruhi hasil segmentasi. Fokus penelitian pada pengembangan metode pra pengolahan untuk meningkatkan kualitas citra dan metode segmentasi otomatis untuk mendeteksi batas nodul secara otomatis pada citra USG payudara. Metode neutrosophic berbasis otsu digunakan untuk memisahkan daerah nodul dengan batas tepi nodul. Berdasarkan hasil segmentasi dengan metode yang diusulkan menunjukkan peningkatan hasil segmentasi citra USG payudara. Hasil segmentasi yang diperoleh antara lain dice coefficient sebesar $82,2 \%$, FP sebesar $23,8 \%$, FN sebesar $13,4 \%$, Housdorff sebesar 48,3 dan MSSD sebesar 354,6. Hasil menunjukkan bahwa metode yang diusulkan mampu mengsegmentasi citra USG payudara secara efektif dan akurat.
\end{abstract}

Kata kunci: Ultrasonografi, Speckle Noise, Neutrosophic Berbasis Otsu

\begin{abstract}
Breast cancer is the leading cause of death among women worldwide. Accurate nodule boundary detection has a significant role in breast cancer diagnosis. An accurate segmentation method is essential for a successful diagnosis. Ultrasound is an effective screening tool for malignancy detection. However, speckle noise existence and low contrast of breast ultrasound images can affect segmentation results. This research focuses on developing a pre-processing method to enhance image quality and conduct an automatic segmentation method to identify the nodule area of breast ultrasound images. Neutrosophic based on the otsu method is used to separate nodule areas with nodule boundaries. Based on the segmentation proposed method that the segmentation results show an increase in the segmentation of breast USG nodule. Neutrosophic based on the otsu method with SRAD filter with normalization has the best performance evaluation. The segmentation results obtained achieve $82.2 \%$ for the dice coefficient, $23.8 \%$ for FP, $13.4 \%$ for FN, 48.3 for Housdorff and 354.6 for MSSD. The result shows that the proposed method is can segment the breast ultrasound images effectively and accurately
\end{abstract}

Keywords : Ultrasonography, Speckle Noise, Neutrosophic Based On Otsu 


\section{PENDAHULUAN}

Kanker adalah penyakit tidak menular yang ditandai dengan pertumbuhan sel tidak normal/terusmenerus dan tidak terkendali yang dapat merusak jaringan sekitarnya serta dapat menjalar ke tempat yang jauh dari asalnya yang disebut metastasis. Sel kanker bersifat ganas dapat berasal atau tumbuh dari setiap jenis sel di tubuh manusia (Depkes RI, 2009). Kanker hingga saat ini menjadi masalah kesehatan di dunia termasuk Indonesia. Jenis kanker yang banyak diderita dan ditakuti oleh perempuan adalah kanker payudara. Pada umumnya kanker payudara menyerang kaum wanita, kemungkinan menyerang kaum laki-laki sangat kecil yaitu 1 : 1000 (Mulyani, 2013; Arafah, 2017).

Kanker payudara merupakan salah satu jenis kanker penyebab kematian diseluruh dunia pada tahun 2012. Berdasarkan International Agency for Research on Cancer (IARC WHO, 2014) penyakit kanker payudara telah menduduki peringkat pertama kanker pada perempuan dibanding jenis kanker lain dan merupakan masalah krusial baik di negara Indonesia, kawasan asia tenggara maupun dunia (Torre et al., 2015). Berdasarkan Pathological Based Registration, Indonesia menempati urutan pertama kanker payudara dengan frekuensi relative sebesar $18,6 \%$, dengan akan kejadian di Indonesia adalah 12/100.000. Di Indonesia lebih dari $80 \%$ kasus ditemukan pada stadium lanjut, sehingga upaya pengobatan sulit dilakukan. Pemahaman upaya pencegahan, diagnosis dini, pengobatan serta upaya rehabilitasi diperlukan untuk dapat mencegah dan meyembuhkan penderita secara optimal (K. K. R. Indonesia, 2015).

Ultrasonografi (USG) merupakan salah satu modalitas penting dalam mendeteksi dan mendiagnosis kanker payudara. Beberapa keunggulan menggunakan pencitraan USG yaitu pemeriksaan USG lebih nyaman dan aman, biaya yang dibutuhkan lebih murah serta proses screening lebih cepat, mengurangi jumlah tindakan biopsy yang tidak perlu, dan memiliki tingkat akurasi yang tinggi. Pembacaan citra USG sangat bergantung pada operator sehingga menjadikan pembacaan citra USG bersifat subjektif. Oleh karena itu untuk mengatasi keterbatasan tersebut dibutuhkan Computer Aided Diagnosis (CAD). CAD merupakan sistem yang dimanfaatkan sebagai penyedia informasi yang bersifat objektif, dengan menguraikan pengetahuan radiologi kedalam teknologi analisis dan pengolahan citra. Penggunaan CAD bukan sebagai pengganti diagnosis dokter atau ahli radiologi, tapi bertujuan sebagai pendapat kedua untuk membantu ahli radiologi dalam meningkatkan akurasi diagnosis. Secara umum, terdapat empat tahapan dalam sistem CAD untk deteksi kanker payudara yaitu pra-pengolahan citra, segmentasi citra, ekatraksi serta seleksi fitur, dan klasifikasi (Nugroho, et al., 2017).

Segmentasi merupakan salah satu bagian penting dalam sistem CAD. Segmentasi otomatis merupakan merupakan salah satu pekerjaan penting dalam pengolahan sinyal. Hal ini berguna untuk melengkapi fasilitas otomatisasi dari sistem CAD. Sistem CAD yang sepenuhnya otomatis dapat meminimalkan efek dari sifat operatordependent. Tingkat akurasi dalam segmentasi sangat penting karena banyak fitur penting untuk membedakan nodul jinak dan ganas berdasarkan karakteristik sesuai dengan Breast imaging, reporting and data system (BI-RADS) (ACR, 2015; Levy, et al., 2017). Fitur-fitur tersebut dapat efektif dikenali setelah batas nodul terdeteksi dengan benar. Dalam beberapa dekade terakhir, metode segmentasi pada citra USG payudara telah banyak diusulkan baik secara otomatis ataupun secara manual. Huang, et al., (2017) berdasarkan hasil survey mengelompokkan metode segmentasi menjadi 7 metode yaitu thresholdingbased, clustering-based, watershedbased, graph-based, active-contour, markop random field dan neural network. Kemudian, Cheng dkk mengeleompokkan metode segmentasi menjadi 4 metode yaitu thresholding method, active contour model, Markov random field, dan neural network. 


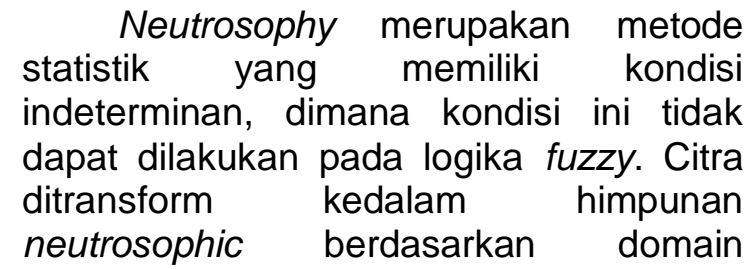
neutrosophic. Ada tiga domain yaitu true (T) yang menyatakan daerah nodul, false (F) yang menyatakan daerah latar belakang dan indeterminan (I) yang menyatakan daerah antara nodul dan latar belakang. Penentuan ketiga domain sangat penting agar proses segmentasi yang diinginkan pada daerah nodul dapat dengan tepat pada bagian tepi nodul dan sesuai dengan kontur yang ditandai oleh ahli radiologi. Beberapa penelitian menggunakan neutrosophy telah banyak diusulkan pada citra USG payudara, seperti: Shan, Cheng, Wang (2012) penelitian ini menggunakan neutrosophic dan I-means dan Guo, Şengür, Tian (2016) fokud penelitian pada neutrosophic dan level set. Nugroho, et al, (2017) menggunakan metode neutrosophic berbasis fuzzy c-means clustering dan neutrosophic berbasis watershed untuk segmentasi pada citra USG.

Proses pra-pengolahan sangat penting dalam merperbaiki kualitas citra untuk mendapatkan hasil segmentasi yang tepat pada daerah nodul (Nugroho, et al., 2017). Berdasarkan literatur yang telah dibahas, segmentasi pada citra USG payudara masih merupakan tantangan besar untuk penelitian lebih lanjut. Dalam penelitian ini, menggunakan teknik hybrid, dengan menggabungkan neutrosophic dengan metode otsu.

\section{METODE}

Metode dalam penelitian ini terdiri dari dua tahap. Tahap pertama adalah pra pengolahan. Pada tahap ini menentukan region of intereset (ROI) pada citra USG dengan cara cropping citra. Selanjutnya proses mengubah citra berwarna ke citra dalam skala keabuan, serta mengurangi speckle noise dengan mennggunakan speckle reduction anisotropic diffusion (SRAD) dan menormalisasi citra dengan menggunakan metode ultrasoundEFT. Tahap terakhir adalah segmentasi citra. pada tahap ini menggunakan segmentasi hybrid yaitu neutosopic set dan metode otsu. Segmentasi citra digunakan untuk mendapatkan kontur pada nodul dan memisahkan nodul dari latar belakang.

Penelitian ini menggunakan citra ultrasonografi 2D yang didapatkan dari database R.S. Sardjito, R.S. Suhardi Hardjolukito dan klinik kotabaru Yogyakarta. Data citra didapat dari dua jenis mesin USG yaitu Logic C5 premium dan Voluson 730 dengan linier tranduser 7 $\mathrm{MHz}$. Citra terdiri dari 102 Citra USG payudara.

\section{Pra Pengolahan}

Proses pra-pengolahan dilakukan dengan empat tahap yaitu pertama melakukan cropping citra pada daerah disekitar nodul, kemudian tahap kedua dengan mengubah citra berwarna menjadi citra dengan skala keabuan, tahap ketiga meningkatkan kontras pada citra dengan menggunakan metode normalisasi dan terakhir tapis citra dengan menggunakan filter Speckle Reduction Anisotropic Diffusion (SRAD) yang bertujuan untuk menghilangkan speckle noise. Gambar 1 menunjukkan diagram blok pra pengolahan pada citra USG payudara.

\section{Normalisasi Citra}

Merupakan suatu metode yang mengskalakan nilai pixel secara linear dengan menggunakan secara penuh jangkauan yang tersedia, dengan tujuan untuk menggunakan seluruh range nilai derajat keabuan sehingga diperoleh gambar yang lebih tajam. Pada penelitian ini menggunakan algoritme normalisasi ultrasoundEFT (Loizou \& CS Pattichis, 2015). Tahapan-tahapan dalam proses normalisasi adalah sebagai berikut:

1. Cari nilai keabuan tertinggi $\left(\max _{-} f\right)$ dan nilai keabuan terendah $\left(\min _{-} f\right)$ dari citra.

2. Cari selisih mutlak antara nilai keabuan terendah dengan nilai keabuan tertinggi, dengan persamaan (1).

$$
d i f_{f}=\left|\max _{-} f-\min _{-} f\right|
$$

3. Hitung nilai pixel pada citra kemudian dipetakan (diskalakan) untuk 
memenuhi rentang nilai-nilai keabuan yang lengkap (0 sampai 255) dengan persamaan (2).

$$
f^{\prime}(x, y)=\left(f(x, y)\left(\frac{255}{d i f_{f}}\right)\right)-\left(\left(\min _{-} f\right)\left(\frac{255}{d i f_{f}}\right)\right)
$$
dengan:

Untuk fungsi normalisasi, sesuai

$$
n(x, y)\left\{\begin{aligned}
0, & \text { if } f^{\prime}(x, y)<0 \\
255, & \text { if } f^{\prime}(x, y)>255
\end{aligned}\right.
$$

dengan:

$$
\begin{aligned}
& f(x, y)=\text { citra asli } \\
& f^{\prime}(x, y)=\text { citra normalisasi }
\end{aligned}
$$

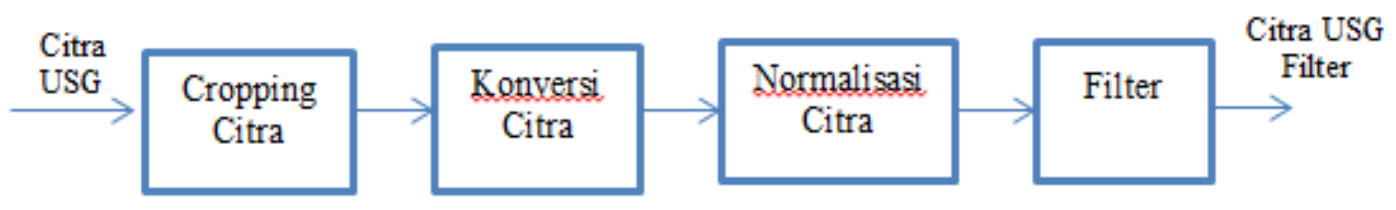

Gambar 1. Diagram Blok Pra Pengolahan

\section{Speckle Reduction Diffusion (SRAD)}

Anisotropic

Speckle noise adalah noise yang terjadi selama proses akusisi citra yang bersifat multiplicative dan locally correlated noise. Proses tapis mengurangi speckle noise tanpa merusak fitur penting dalam citra. Filter SRAD yang diususlkan oleh Yu, dkk (Yu, Acton, 2002) menggabungkan metode anisotropic diffusion (AD) yang diusulkan oleh Frost dan filter adaptif mean yang diusulkan oleh Lee. Teknik ini berdasarkan Partial Differential Equation (PDE) dan Minimum Mean Square Error (MMSE).

Filter SRAD adalah metode yang menggantikan metode edge detector dalam metode anisotropic diffusion dengan koefisien instantaneous dengan variasi optimum yang sesuai dengan penapisan speckle (Balodi, Dewal, Rawat, 2015). Magnitud gradien dan operator laplacian sebagai deteksi tepi merupakan fungsi koefisien instantaneous.

Jika pixel pada citra direperesentasikan sebagai $I_{0}(x, y)$ dan urutan nilai dari batas nodul dihitung dan bukan nol dalam sebuah citra $\Omega$, kemudian nilai dari persamaan turunan parsial (PDE) dari $\mathrm{I}(\mathrm{x}, \mathrm{y}$; t) (Jatmiko et al., 2013) diberikan pada persamaan (3).

$$
\begin{aligned}
& \left\{\begin{array}{c}
\frac{\delta I(x, y ; t)}{\delta t} \\
I(x, y ; 0)=I_{0}(x, y),(\delta I(x, y ; t) / \delta n) \mid \delta \Omega
\end{array}\right. \\
& =\operatorname{div}[c(q) . \nabla I(x, y ; t))
\end{aligned}
$$

dengan:

$$
\begin{aligned}
& \Delta \Omega=\text { batas citra } \Omega \\
& \nabla \mathrm{I}(\mathrm{x}, \mathrm{y} ; \mathrm{t})=\text { citra asli } \\
& (\Delta \mathrm{I}(\mathrm{x}, \mathrm{y} ; \mathrm{t})) / \delta \mathrm{t}=\text { PDE dari } \mathrm{I}(\mathrm{x}, \mathrm{y} ; \mathrm{t})
\end{aligned}
$$

Untuk mengontrol seberapa banyak smoothing yang dilakukan pada pixel yang mengginakan koefisien instantaneous dalam fungsi difusi diberikan pada persamaan (4) (Loizou, CS Pattichis, 2015).

$$
\operatorname{Csrad}^{2}=\frac{\frac{1}{2}|\nabla I|^{2}-\frac{1}{16}\left(\nabla^{2} I\right)^{2}}{\left(I+\frac{1}{4} \nabla^{2} I\right)^{2}}
$$

Nilai filter SRAD dihitung dengan persamaan (5).

$$
\operatorname{Israd}=I+\frac{1}{\eta_{s}} \operatorname{div}(\operatorname{Csrad} . \nabla I)
$$

\section{Segmentasi}

Tahap kedua adalah proses segmentasi yang bertujuan memisahkan nodul dari latar belakang untuk mendapatkan kontur pada nodul. Metode Segmentasi berdasarkan metode hybrid yang menggabungkan neutrosohpic dan metode otsu. 


\section{Neutrosophic}

Neutrosophy merupakan metode statistik untuk mengatasi kondisi indeterminan, yang tidak dapat ditangani dengan metode logika fuzzy. Pada neutrosophy citra ditransform ke himpunan neutrosophic berdasarkan domain neutrosophic. Himpunan bagian dari $\{T, I, F\}$ mewakili pixel dalam domain neutrosophic. Hal ini menunjukkan pixel sebagi $\mathrm{t} \%$ true, $\mathrm{i} \%$ indeterminate and $\mathrm{f} \%$ false, dimana $\mathrm{t}$ bervariasi dalam $\mathrm{T}$, $\mathrm{i}$ bervariasi dalam I and $f$ bervariasi dalam $\mathrm{F}$

\section{Otsu}

Metode otsu dikembangkan oleh Nobuyuki Otsu pada tahun 1979, dengan menentukan nilai ambang untuk membagi citra menjadi objek dan latar belakang. Metode otsu merupakan jenis segemntasi berdasarkan deteksi tepi (edge detection). Segmentasi berdasarkan tepi adalah proses segmentasi untuk mendapatkan garis yang ada pada gambar dengan anggapan bahwa garis tersebut merupakan tepi dari obyek yang memisahkan obyek satu dengan obyek yang lain atau antara obyek dengan background (Pradipta, Ayu, 2017). Pada pendekatan neutrosophic, metode otsu digunakan untuk segmentasi citra dengan langkah-langkah sebagai berikut:

1. Memetakan dan menentukan himpunan $\{T, F\}$.

2. Enhancement.

3. Mendapatkan batas ambang (threshold) dalam T dan F.

4. Menentukan kehomogenan daerah intensitas dan menentukan himpunan $\{l\}$.

5. Mengkonversi citra ke citra biner berdasampan himpunan $\{\mathrm{T}, \mathrm{I}, \mathrm{F}\}$.

6. Menerapkan metode otsu ke citra biner yang telah dikonversi.

\section{EVALUASI KINERJA}

Pada penelitian ini ada dua jenis evaluasi kinerja yang digunakan yaitu area metrics dan boundary metrics. Evaluasi ini digunakan untuk mengukur secara kuantitatif performa hasil segmentasi dengan gold standart.

\section{Area Metrics}

Area metrics dapat mengevaluasi seberapa besar area nodul yang benar dan daerah nodul yang salah yang dapat dipenuhi oleh daerah nodul yang dihasilkan. Persamaan false positive (FP), false negative (FN) dan dice coefficient (Dice) dihitung masing-masing berdasarkan persamaan (6), (7) dan (8).

$$
\begin{gathered}
F P R=\frac{\left|A_{g} \cup A_{s}-A_{g}\right|}{\left|A_{g}\right|} \\
F N=\frac{\left|A_{g} \cup A_{s}-A_{s}\right|}{\left|A_{g}\right|} \\
\text { Dice }=\frac{2\left(A_{g} \cap A_{s}\right)}{\left|A_{g}\right|+\left|A_{s}\right|}
\end{gathered}
$$

dengan:

$A_{s}=$ Himpunan pixel daerah nodul yang dihasilkan secara otomatis dengan metode yang diusulkan.

$A_{g}=$ Himpunan pixel daerah nodul yang digambarkan secara manual oleh ahli radiologi.

\section{Boundary Metrics}

Boundary metrics menganalisa perbedaan antara kontur yang dihasilkan dari metode yang dihasilkan dan kontur yang ditandai secara manual oleh ahli radiologi. Dua jenis pengukuran digunakan untuk evaluasi kinerja hasil segmentasi, antara lain Housdorff dintance (HD) dan mean sum of square distance (MSSD) yang didefinisikan dalam persamaan (9) dan (10).

$$
\begin{gathered}
H D=\max _{j} d\left(p_{j}, Q\right), j=1, \ldots, \mu \\
M S S D=\frac{\sum_{j=1}^{\mu} d^{2}\left(p_{j}, Q\right)}{\mu}
\end{gathered}
$$

dengan:

$$
\begin{array}{ll}
Q & =\begin{array}{l}
\text { Himpunan batas yang } \\
\text { digambar secara manua }
\end{array} \\
P & =\text { Himpunan batas hasil } \\
& \text { segmentasi } \\
d\left(p_{j}, Q\right)= & \text { jarak Euclidean minimu } \\
H D & =\text { maksimum dari } d\left(p_{j}, Q\right)
\end{array}
$$




$$
\begin{array}{ll}
\gamma & =\text { Jumlah pixe/ batas pada } \\
& \text { kontur } Q \\
\mu & =\text { Jumlah pixel batas pada }
\end{array}
$$

HD mengukur ketidaksesuaian antara dua kontur, sementara MDSS mengukur ketidaksesuain rata-rata antara dua batas nodul.

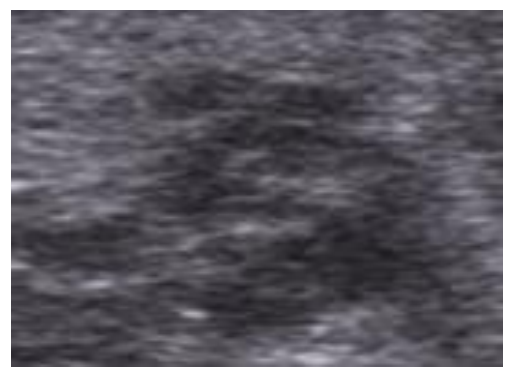

\section{HASIL DAN PEMBAHASAN}

Penelitian ini menggunakan 102 citra USG payudara yang diperoleh dari 3 database rumah sakit dan dilengkapi dengan hasil patologi anatomi. Contoh nodul payudara ditunjukkan pada

Gambar 1.

Gambar 1. Nodul citra USG payudara

\section{Pra Pengolahan}

Region of Interest (Rol) merupakan proses penentuan daerah yang mengandung nodul berdasarkan tanda dari ahli radiologi. Beberapa citra USG payudara mengandung label dan marker, sehingga penting untuk dihilangkan. Filter adaptif median efektif dalam meyelesaikan permasalahan tersebut tanpa menimbulkan efek kabur pada citra.

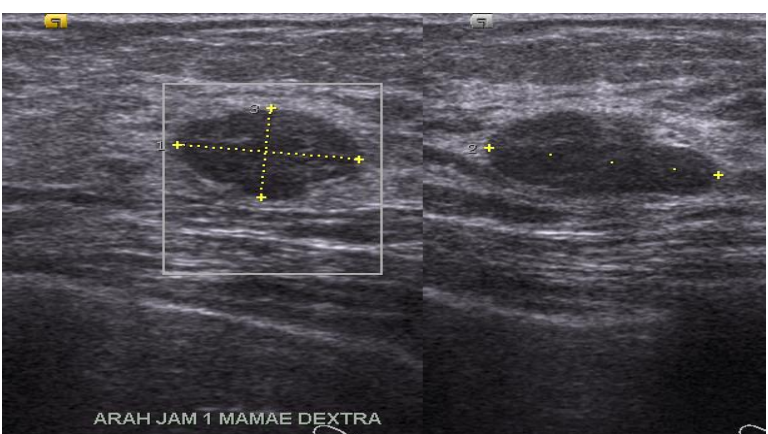

(a)

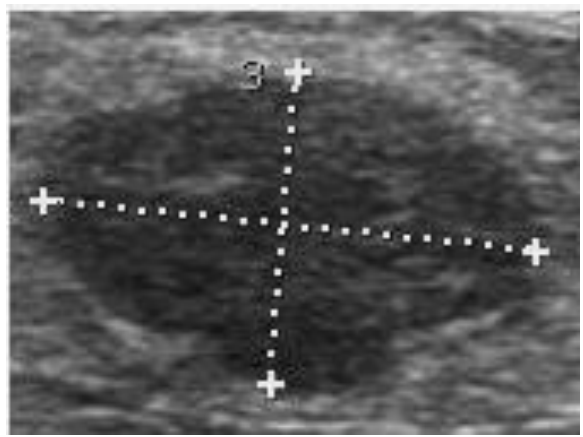

(c)
Hasil dari proses pra-pengolahan ditunjukkan pada

Gambar 2.

Tujuan dari normalisasi citra adalah untuk meningkatkan kontras pada citra. Filter SRAD dapat menguragi speckle noise tanpa merusak bagian tepi dari objek. Gambar 3 menunjukkan hasil normalisasi dan hasil filter SRAD.

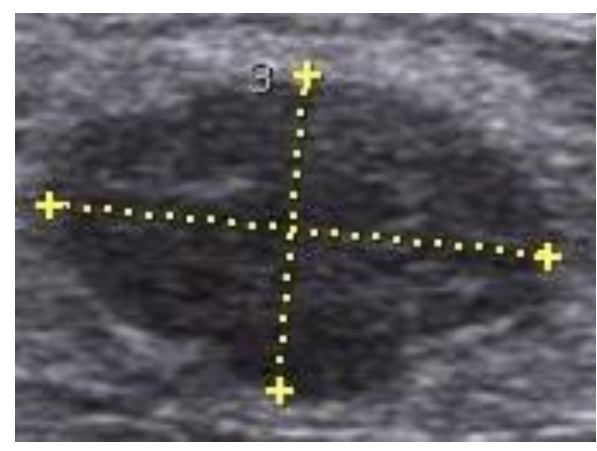

(b)

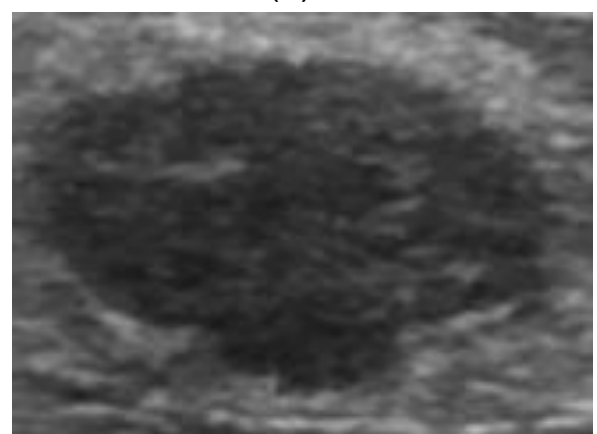

(d) 
Gambar 2. (a) Citra asli (b) Citra Rol (c) Citra grayscale (d) Citra filter

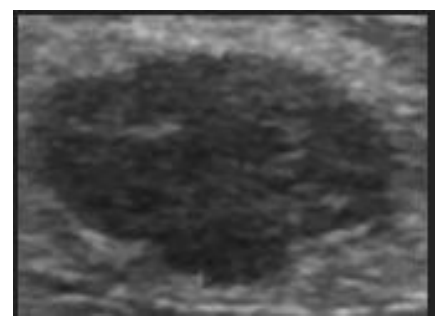

(a)

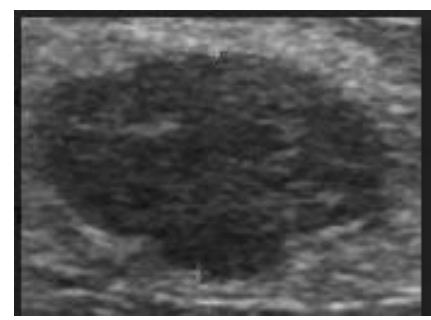

(b)

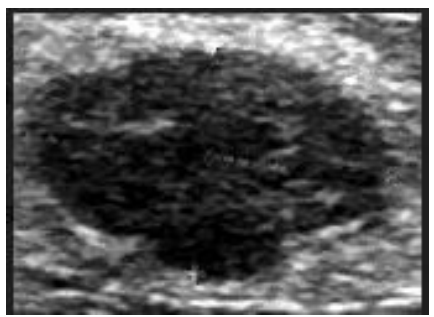

(c)

Gambar 3. (a) Citra asli (b) citra SRAD (c) citra SRAD dengan normalisasi

\section{Segmentasi}

Teknik hybrid berdasarkan neutrosophic dan metode otsu diusulkan untuk segmentasi pada citra USG payudara. Pada penelitian T adalah objek dan $\mathrm{F}$ adalah latar belakang. Tepi yang kabur secara berangsur-angsur mengalami perubahan dari objek ke latar belakang, dan tidak ada batas yang jelas antara objek dan tepi objek atau antara latar belakang dengan tepi latar belakang. Batas yang kabur didefinisikan dengan I. Gambar 4 menunjukkan hasil segmentasi nodul menggunakan algoritma neutrosophic berdasarkan metode otsu. Gambar 5 menunjukkan contoh segmentasi pada daerah nodul dengan dua metode. Dari hasil segmentasi, metode yang diusulkan dapat mensegment area nodul secara lengkap dan halus serta dapat mempertahankan dengan baik informasi penting untuk diagnosis, seperti dearah tepi dan batas dari nodul. Batas nodul yang diidentifikasi dengan metode yang berbeda diletakkan pada citra asli dengan menggunakan garis merah. Hasil segmentasi neutrosophic berdasarkan otsu lebih akurat dan lebih dekat dengan ground truth dibandingkan dengan otsu.

Untuk mengevaluasi hasil segmentasi secara kuantitatif, lima pengukuran digunakan untuk membandingkan hasil segmentasi yang disusulkan dengan hasil segmentasi manual oleh ahli radiologi. Batas nodul yang secara manual dibuat oleh ahli radiologi berpengalaman yang digunakan sebagai standar acuan untuk evaluasi kinerja segmentasi pada daerah nodul.

Total 102 gambar dipilih dari 2 kasus dan batas nodul secara manual ditentukan, yang digunakan sebagai standar acuan untuk evaluasi kinerja. 2 kasus perwakilan mencakup sebagian besar kategori kanker payudara sesuai dengan data set yang kami miliki. Hasil segmentasi dibandingkan dengan segmentasi manual oleh ahli radiologi, berdasarkan evaluasi kinerja dice coefficient (Dice), false negative (FN), false positive (FP), Housdorff (HD) dan mean sum of square distance (MSSD) dihitung pada citra yang sesuai.

Seperti ditunjukkan pada

Tabel 1 Dice, FP, HD dan MSSD meningkat dari $79,0 \%, 54,8 \%, 54,9$ pixel dan 465,6 pixel menggunakan metode otsu menjadi $82,2 \%, 23,8$ pixel, dan 354,6 pixel menggunakan metode neutrosophic berdasarkan otsu. Namun sebaliknya, FN mengalami penurunan kinerja dari $1,1 \%$ menggunakan metode otsu menjadi $13,4 \%$ menggunakan metode neutrosophic berdasarkan otsu. Namun, penurunan kinerja pada FN diimbangi oleh peningkatan kinerja FP.

Perbandingan

tersebut menunjukkan bahwa metode neutrosophic berdasarkan otsu dapat mencapai kinerja yang lebih baik daripada metode otsu Kita dapat menarik kesimpulan bahwa metode neutrosophic berdasarkan otsu bisa digunakan untuk segmentasi nodul pada citra USG payudara berdasarkan percobaan dan evaluasi pada citra medis. 


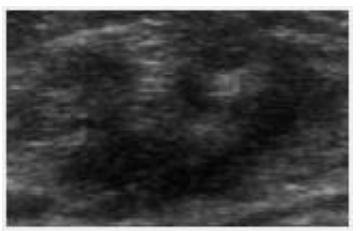

(a)

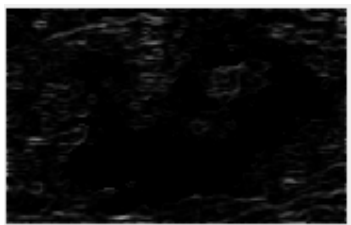

(d)

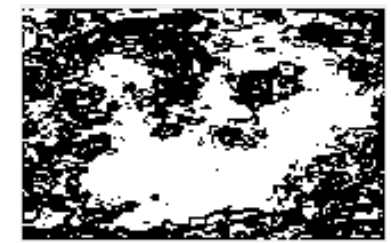

(g)

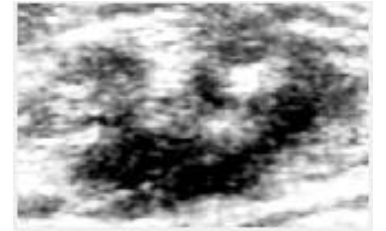

(b)

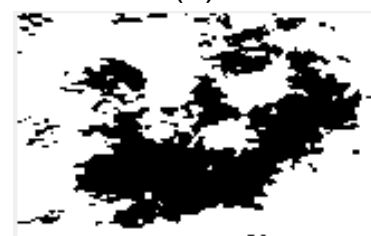

(e)

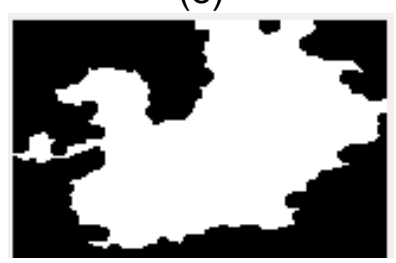

(h)

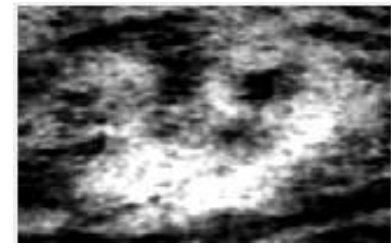

(c)

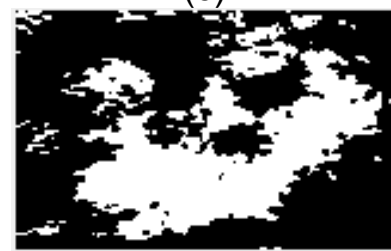

(f)

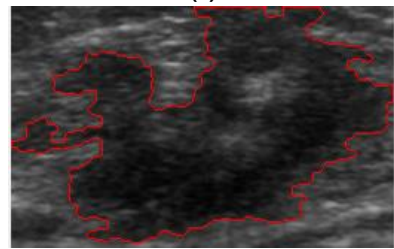

(i)

Gambar 4. (a) citra pra-pengolahan (b) T-domain (c) F-domain (d) indeterminate image (e) otsu untukT-domain (f) otsu untuk F-domain (g) citra biner berdasarkan T,I,F (h) segmentasi biner (i) nodul hasil segmentasi.
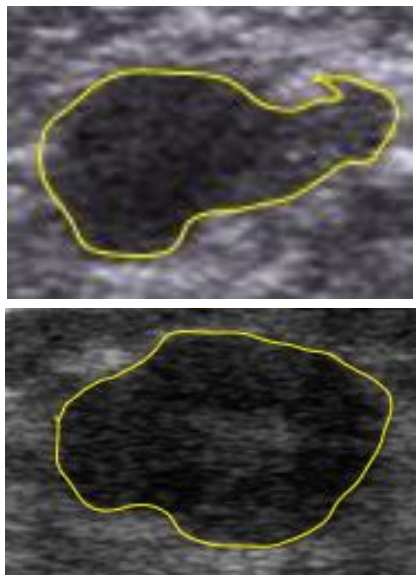

(a)
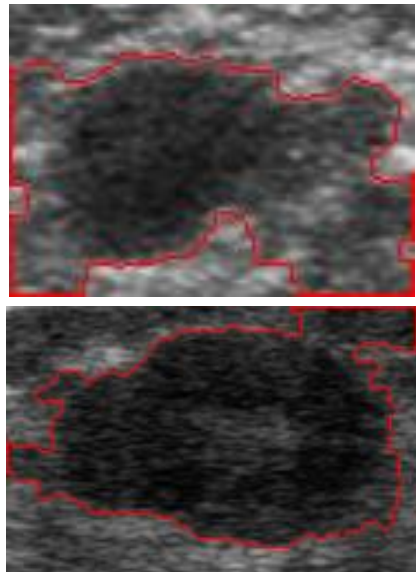

(b)
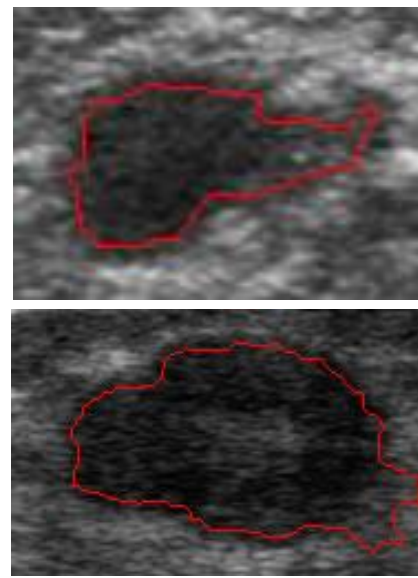

(c)

Gambar 5. Contoh hasil segmentasi citra dengan metode yang berbeda: (a) ground truth (b) hasil segmentasi dengan metode otsu (c) hasil segmentasi neutrosophic berdasarkan otsu

Tabel 1. Evaluasi Kinerja Metode Segmentasi.

\begin{tabular}{lccccc}
\hline \multirow{2}{*}{ Metode } & \multicolumn{3}{c}{ Rata-rata area metrics } & \multicolumn{2}{c}{ Rata-rata boundary metrics } \\
\cline { 2 - 6 } & Dice (\%) & FN (\%) & FP (\%) & HD (pixel) & MSSD (pixel) \\
\hline Otsu & 79,0 & 1,1 & 54,8 & 54,9 & 465,6 \\
Neutrosophic otsu & 82,2 & 13,4 & 23,8 & 48,3 & 354,6 \\
\hline
\end{tabular}




\section{SIMPULAN}

Penelitian ini menunjukkan bahwa neutrosophic berdasarkan metode otsu dapat meningkatkan hasil segmentasi nodul citra USG Payudara. Segmentasi nodul secara otomatis dan akurat merupakan langkah mendasar pada banyak tugas analisis citra dan computer aided diagnosis (CAD) pada citra USG payudara, dan metode yang diusulkan akan menemukan lebih banyak aplikasi pada area segmentasi.

\section{DAFTAR PUSTAKA}

ACR. 2015. ACR BI-RADS. Atlas Fifth Edition.

Arafah, Alvita Brilliana R. Faktor Yang Berhubungan Dengan Perilaku lbu Rumah Tangga Melakukan Pemeriksaan Payudara Sendiri (Sadari) . Journal of Public Health.12(2). 143-153

Balodi, A., Dewal, M. L., \& Rawat, A. 2015. Comparison of despeckle filters for ultrasound images. 2nd International Conference on "Computing for Sustainable Global Development". 1919-1924.

Guo, Y., Şengür, A., \& Tian, J.-W. 2016. A novel breast ultrasound image segmentation algorithm based on neutrosophic similarity score and level set. Computer Methods and Programs in Biomedicine. 123. 4353.

Huang, Q., Luo, Y., \& Zhang, Q. (2017). Breast ultrasound image segmentation: a survey, 493-507.

Jatmiko, W., Mursanto, P., Hardian, B., Bowolaksono, A., Wiweko, B., Akbar, M. A.,Kurniawan, M. N. 2013. Teknik Biomedis: Teori dan Aplikasi. (F.I.K.U. Indonesia, Ed.) Jakarta: UIP.

Levy, L., Suissa, M., Chiche, J. F., Teman, G., \& Martin, B. 2017. BIRADS ultrasonography. European Journal of Radiology, 61(2), 202-211.

Loizou, C. P., \& CS Pattichis. 2015. Despeckle Filtering for Ultrasound Imaging and Video Volume I: Algorithms and Software. (A. S. U. Andreas Spanies, Ed.)Synthesis Lectures on Algorithms and Software for Engineering (Second).
Cyprus: Morgan \& Claypool Publishers.

Nugroho, H. A., Rahmawaty, M., Triyani, Y., \& Ardiyanto, I. 2017. Neutrosophic and Fuzzy C-Means Clustering for Breast Ultrasound Image Segmentation. In The 9th International Conference on Information Technology and Electrical Engineering (ICITEE 2017).

Nugroho, H. A., Rahmawaty, M., Triyani, Y., \& Ardiyanto, I. 2017. Texture Analysis and Classification in Ultrasound Medical Images for Determining Echo Pattern Characteristics. 2017 7th IEEE International Conference on System and Technology (ICSET).

Nugroho, H. A., Triyani, Y., Rahmawaty, M., \& Ardiyanto, I. 2017b. Breast Ultrasound Image Segmentation Based on Neutrosophic Set and Watershed Method for Classifying Margin Characteristics. In 017 7th IEEE International Conference on System and Technology (ICSET). 43-47).

Nugroho, H. A., Triyani, Y., Rahmawaty, M., \& Ardiyanto, I. (2017c). Computer Aided Diagnosis using Margin and Posterior Acoustic Featuresfor Breast Ultrasound Images, 15(4), 1776-1784.

Pradipta, G. A., \& Ayu, P. D. W. (2017). Perbandingan Segmentasi Citra Telur Ayam Menggunakan Metode Otsu Berdasarkan Perbedaan Ruang Warna Rgb Dan Hsv. Jurnal Sains Dan Teknologi, 6(1), 136-147.

Shan, J., Cheng, H. D., \& Wang, Y. (2012). A novel segmentation method for breast ultrasound images based on neutrosophic I-means clustering. Medical Physics, 39(9), 5669-5682.

Torre, L. a., Bray, F., Siegel, R. L., Ferlay, J., Lortet-tieulent, J., \& Jemal, A. (2015). Global Cancer Statistics, 2012. CA: A Cancer Journal of Clinicians., 65(2), 87-108. Yu, Y., \& Acton, S. T. (2002). Speckle reducing anisotropic diffusion. IEEE Transactions on Image Processing. 